\title{
Seasonal and nutritional effects on serum proteins and urea concentration in the reindeer (Rangifer tarandus tarandus $\mathrm{L}$.)
}

\author{
BY H. HYVÄRINEN, T. HELLE, R. VÄYRYNEN AND \\ P. VÄYRYNEN \\ Department of Zoology, University of Oulu, g0100 Oulu 10, \\ Finland
}

(Received 8 March 1974 - Accepted 15 May 1974)

\begin{abstract}
r. The effects of seasonal conditions and nutrition on serum proteins and serum urea concentrations were studied in female reindeer and reindeer calves in Finland. With the exception of one group in winter, the reindeer were roaming wild in the forests. This one group was kept in captivity, out of doors, on a comparatively high nutritional plane. One group lived wild during the winter in very poor nutritional conditions.

2. A very clear seasonal variation in the serum protein and urea concentration was found. The serum protein concentration was low in late winter and increased rapidly during the summer, being high in the autumn. The serum urea concentration was also low in the winter and high in the summer. In the autumn, however, the serum urea concentration was again low.

3. Changes in the serum protein concentration were normally associated with the serum globulins. Only in the very poor-nutrition group did the albumin content decrease signifcantly. As a result of the large changes in the concentration of serum globulins, there were also considerable changes in the albumin: globulin ratio.

4. The serum protein concentration was much lower in the reindeer calves than in the adult reindeer. The concentration of globulins in particular was much lower than in the adults.
\end{abstract}

The reindeer (Rangifer tarandus tarandus L.) lives in the arctic, subarctic or boreal areas of Finland in almost the same conditions as a wild animal. There are marked seasonal variations in the environment of these animals. The period of snow cover lasts about $180-210 \mathrm{~d} / \mathrm{year}$, and the depth and hardness of the snow are very important factors in determining the reindeer's chances of finding enough food during the winter. The early spring is the most critical part of the year. In some years crusted snow and ice sheets on the ground can cause the reindeer to suffer from severe malnutrition, and in catastrophic years large numbers may die.

During the period of snow cover the reindeer eat lichens (Cladonia spp.), which they must dig for in the snow. In the southern part of the reindeer husbandry area they can also eat arboreal lichens, especially Alectoria spp., and frozen Deschampsia flexuosa hay (Sulkava $\&$ Helle, 1972), but these are not available in the northern part. The nutritive value of lichens, particularly the protein and mineral content, is very low compared with that of the reindeer's summer food (cf. Steen, I968). However, there is very little information about the factors most involved in causing the mortality of reindeer in catastrophic years.

In this study we examined the changes in serum proteins and serum urea concentration of female reindeer that occurred at a time of most severe conditions, just before a catastrophe in which a large number of reindeer died, and compared these results with those obtained for other seasons and those for the same time of the year but under better nutritional conditions. 


\section{MATERIALS AND METHODS}

Animals and diets. The reindeer were divided into five groups. Groups $\mathrm{I}, 2$ and 3 were adult female reindeer from which blood samples were taken within a period of a month, March-early April.

Group I was reared in captivity out of doors in Kuusamo $\left(66^{\circ} 30^{\prime} \mathrm{N}\right)$ and was maintained in a good nutritional state on dry hay, dry leaves of Betula pubescens and lichens. This food was always available.

Group 2 was left to roam wild in the forests of Kuusamo with a comparatively good food supply. They ate lichens (Alectoria spp.) from felled trees at timber-cutting sites. The reindeer were captured using a foot noose.

Group 3 was living wild in Enontekiö, in Finnish Lapland $\left(68^{\circ} 30^{\prime} \mathrm{N}\right)$. In this area the reindeer had great difficulty in digging for lichens because of the hard crust on the snow. Here there were no Alectoria spp. for them to feed on. At the time when the blood samples were taken the reindeer were already in a poor nutritional state and soon afterwards it became known that a large number had died in this area. In Enontekiö the reindeer were captured by lasso.

Group 4 consisted of wild roaming female reindeer $(4 \mathrm{~A})$ and their $1-2$-month-old calves $(4 \mathrm{~B})$. The blood samples were taken during the marking of the calves in the summer in late June and early July in Kuusamo. These reindeer had been eating food of high nutritional value for I month, e.g. leaves of Betula and Salix.

Group 5 consisted of wild roaming female reindeer $(5 \mathrm{~A})$ and their 4 -5-month-old calves $(5 \mathrm{~B})$. The animals were captured and the blood samples taken during the marking of reindeer in the register at the beginning of October. At this time they were beginning their winter feeding regimen but had been eating mostly Equisetum fluviatile, Menyanthes trifoliata, Chamaenerion angustifolium and Boletus spp. in mid and late summer. The crude-protein content of these foods was very high (Table 4 ).

Analytical methods. The blood samples were taken from the jugular vein immediately after capture, and the reindeer were then weighed. The serum protein content was determined using the Biuret method (Schlieper, 1965). The electrophoretic separation of the serum proteins was done using cellulose acetate and polyacrylamide gels. Polyacrylamide gel electrophoresis was done by the method of Pleuger (r 969 ). Barbital buffer, $\mathrm{pH} 8.6$ and ionic strength $0.075 \mu$ (Millipore Corp., I968), was used for the cellulose acetate gels. Serum urea concentration was determined using the Nesslerization method (Annino, r964).

Statistical analysis. The $t$ test was used to test the significance of differences between group mean values.

\section{RESULTS}

\section{Changes in body-weight}

For the groups studied in the winter (groups $\mathrm{I}-3$ ) the body-weights were significantly higher in each of the Kuusamo groups (groups I and 2) than in the Enontekiö group (group 3) (Table I). The body-weights of the reindeer in Kuusamo decreased during the spring, and at the end of June the values were about 10\% lower than those 
Table I. Body-weights $(\mathrm{kg})$ of female reindeer over 4 years old and their calves maintained in captivity or in the wild in different seasonal and nutritional conditions

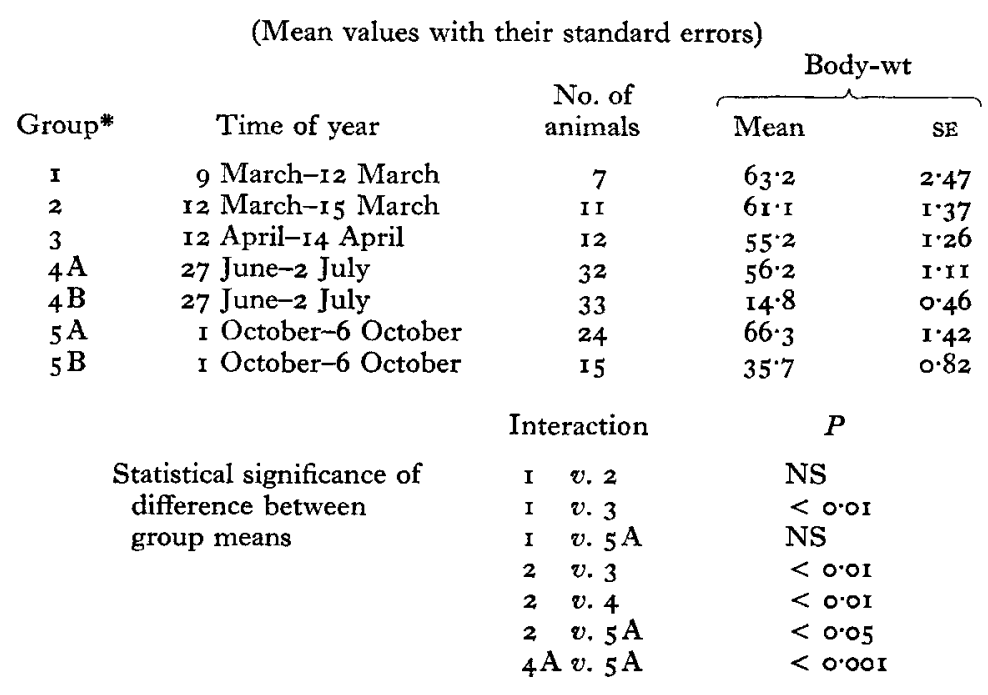

NS, non-significant.

* For details of groups, see p. 64 .

obtained in March. This weight decrease may have been the result of calving, since the newborn calves weigh about 4-6 kg (Varo, 1973). During the summer the weight increased rapidly and in October it was about $20 \%$ higher than in the summer. The weight of the reindeer calves increased by about $130 \%$ during the three summer months.

\section{Seasonal changes in serum protein concentration and composition, and in serum urea concentration}

The serum protein concentration was highest in the samples taken in the autumn (group $5 \mathrm{~A}$ ) and lowest in the samples taken in late winter (groups 2 and 3 ). During the summer (group $4 \mathrm{~A}$ ) the serum protein concentration was higher than during the winter (groups $\mathrm{I}-3$ ), and this pattern of increase continued from the summer into the autumn (Fig. I, Table 2). These changes were significant, and the results suggest that they were mainly due to changes in serum globulins. The change in serum albumin concentration was comparatively small. The albumin:globulin ratio was thus found to be much higher in the winter (due to the low globulin content) than it was in the summer and, especially, the autumn (Fig. I, Table 2). Serum globulins also increased in the reindeer calves from the summer to the autumn, but the total globulin content was clearly lower than in the adults. This pattern was also suggested by the results of serum electrophoresis (Fig. 2).

The serum urea concentration was low in the winter and the autumn compared with that in the summer (Table 3 ). The values for serum urea concentrations in 


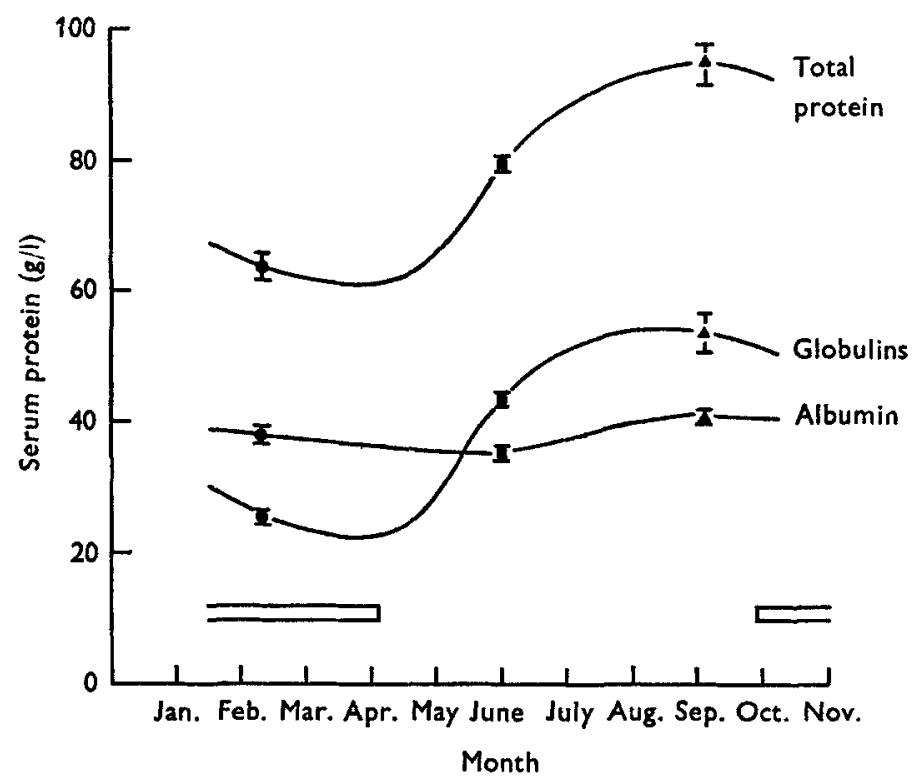

Fig. I. Seasonal changes in the concentrations of serum proteins in groups of adult female reindeer maintained in the wild in the forests of Kuusamo. $\mathbf{0}$, Group 2; $\mathbf{m}$, group $4 \mathrm{~A}$; $\boldsymbol{\Delta}$, group $5 \mathrm{~A}$; for details of groups see p. 64. Mean values with their standard errors represented by vertical bars. $\square$, Period of snow cover.

reindeer are very markedly affected by exercise or disturbance. During $2 \mathrm{~d}$ spent impounded in an enclosure the serum urea concentration can increase $7-8$ times (Hyvärinen \& Helle, I974). Therefore only animals which had been disturbed very little, less than $2 \mathrm{~h}$ in an enclosure for the groups studied in the summer and autumn, were used for urea determination.

\section{Effects of winter conditions and nutrition on serum protein concentration and composition and on serum urea concentration}

Total serum protein concentration was highest in the supplementary-feeding group (group I) and lowest in the group maintained under poor nutritional conditions (group 3). In particular the serum globulin content of group I was higher than that of groups 2 and 3 , and this was the major part of the difference in total protein concentration between groups $\mathrm{I}$ and 2 (Table 2 ). In group 3 the serum albumin concentration was also significantly lower than that in group 2 , and the globulin concentration was even lower than in group 2. The albumin: globulin ratio was lowest in group I.

Serum urea concentration (Table 3 ) was significantly higher in group I than in group 2 , and even in group 3 it was significantly higher than in group 2. In group 3 the serum urea concentration was highest in those animals whose serum protein concentration was lowest $(r 0.87)$. 


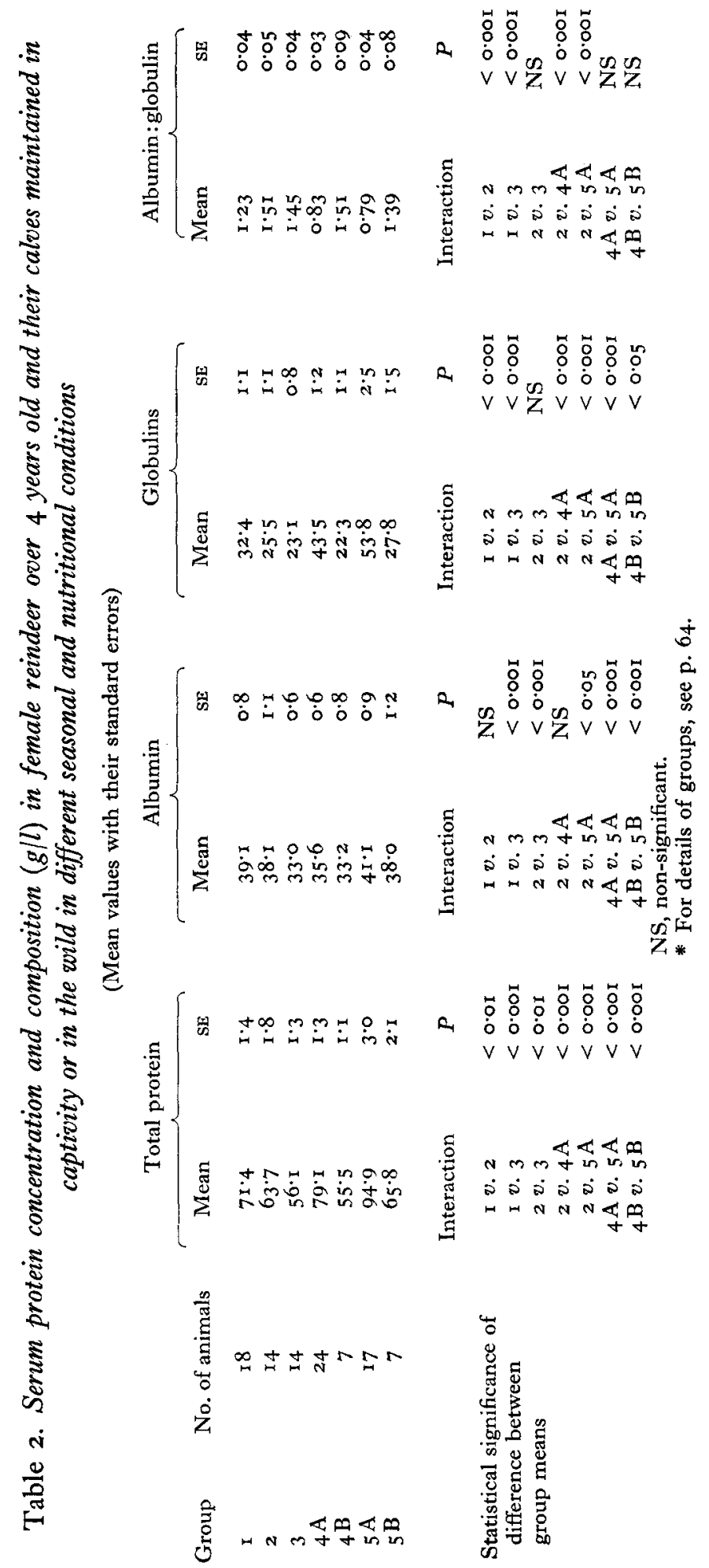


(A)

(a)

(b)

Albumins
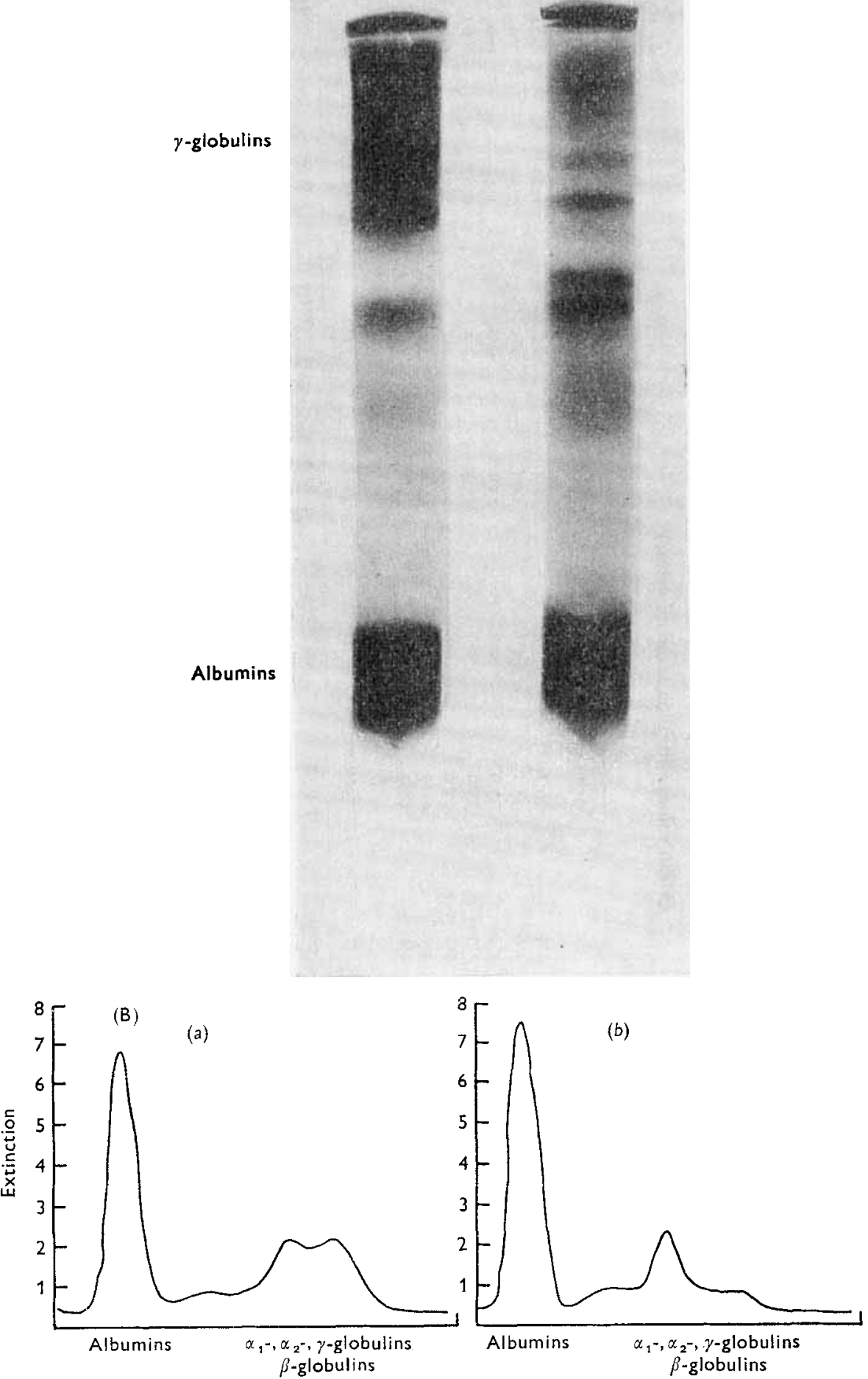

Fig. 2. Pattern of serum proteins separated by electrophoresis on polyacrylamide gel (A) and densitometric curves for serum proteins separated by electrophoresis on cellulose acetate (B) for $(a)$ an adult female reindeer and $(b)$ her calf aged I month. The proportion of $\gamma$-globulins in the calf was very low compared with that in the adult, but the corresponding proportion of possible $\alpha$-globulins was comparatively higher than that in the adult. 
Table 3. Serum urea $(S U)$ concentrations (mmol/l) in undisturbed* female reindeer over 4 years old and their calves, maintained in captivity or in the wild in different seasonal and nutritional conditions

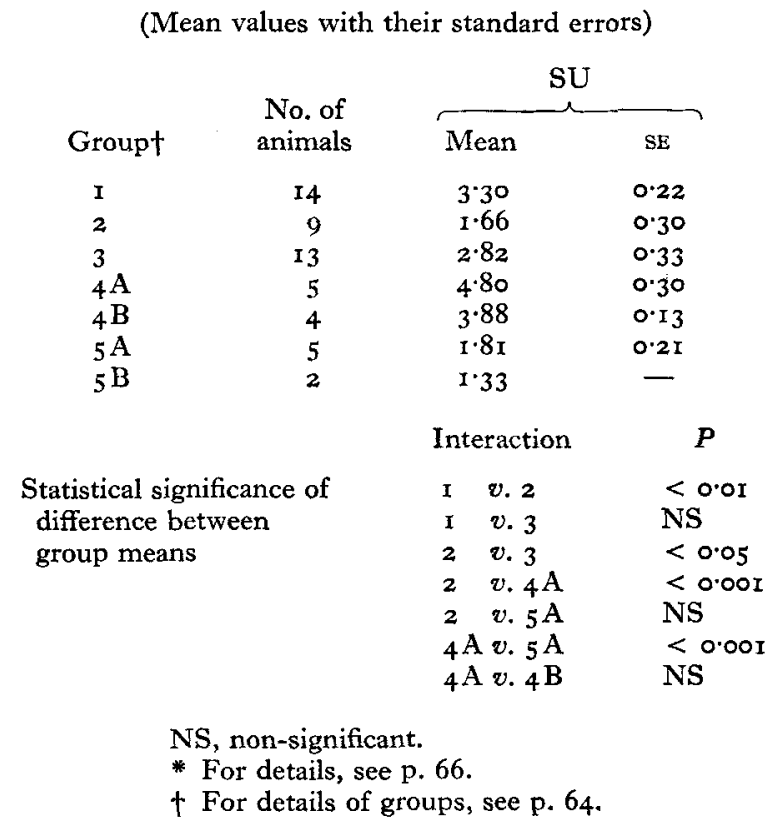

\section{DISCUSSION}

There are clear seasonal changes in serum proteins and serum urea concentration in reindeer. Similar changes have also been found by workers in the USSR and Canada (Afanas'ev, I963; McEwan, I968b), although values for seasonal variations in serum protein concentration were not as high as those found here. These changes are presumably associated with changes in available nutrients. It is well known that the normal winter food of reindeer and caribou is very poor in proteins and minerals (Kelsall, I968; Steen, 1968; Westerling, 1969; McEwan \& Whitehead, 1970). The reindeer have adapted to this situation, however, and in normal years when digging conditions are good, wintering and reproduction are quite successful. The energy value of lichens is comparatively high because of their high carbohydrate content, although their protein and mineral content is low (Isotalo, I97I ; Westerling, I973). A clear seasonal variation has also been observed in glucose metabolism of the reindeer (Cameron \& Luick, 1972; Luick, Person, Cameron \& White, 1973), and it has been found that hydrocortisone secretion is more intensive during winter than during summer (Yousef, Cameron \& Luick, r 971).

During the summer the reindeer are eating food of high nutritive value (Steen, r968), and it is during this time that the animals grow and gather body reserves for winter use(Klein, I968; McEwan, I968a). This can be seen in the seasonal changes in the body-weights of the animals and also in the changes in serum protein concentration 
Table 4. Crude-protein content of the most important food sources of the reindeer in Finland (Isotalo, 197I ; SITRA (Suomen Itsenäisyyden Rahasto) investigation team, Finland, unpublished results)

Plant species
Alectoria spp.
Cladonia spp.
Phleum pratense
Deschampsia flexuosa
Betula
Salix
Menyanthes trifoliata
Equisetum spp.
Chamaenerion angustifolium
Boletus spp.

Crude protein (nitrogen $\times 6 \cdot 25)$
$(\mathrm{g} / \mathrm{kg}$ dry weight)
$29-75$
$20-44$
$67-106$
$67-107$
$127-224$
$129-260$
$103-229$
$135^{-182}$
$143^{-253}$
$184-256$

and composition and in serum urea concentration. The crude-protein content of lichens, of the hay and dry leaves used in this study as supplementary feed, and also that of the most important food sources of the reindeer during the summer months (Menyanthes trifoliata, Equisetum fluviatile, Chamaenerion angustifolium, Boletus spp.), shown in Table 4, are values reported by Isotalo (1971) and the unpublished results of the SITRA (Suomen Itsenäisyyden Rahasto) investigation team in Finland.

The crude-protein content of lichens of the Cladonia spp. is very low while that of Alectoria spp. is higher, and that of young, dry leaves of Betula and Salix is especially high. The summer food contains many times more protein than the winter food. The reindeer in group I were receiving food of comparatively high crude-protein content during the winter and this was reflected in the higher serum protein concentration and also in the comparatively high serum urea concentration. It is known that in protein malnutrition the total serum protein concentration decreases (Grimble, Sawyer \& Whitehead, 1969). Under normal circumstances this is achieved by a decrease in the serum albumin concentration, resulting in a decrease in the albumin: globulin ratio. In the reindeer studied here and also in those studied by Afanas'ev (1963), the decrease in serum protein is at first associated with a decrease in serum globulin concentration, and the albumin:globulin ratio thus increases. It is obvious that reindeer are comparatively well adapted to seasonal variations in food composition, and the high concentration of globulins in autumn may represent reserve protein for the winter. The serum albumin content was also lower in group 3, which must be occasioned by protein malnutrition. Grimble et al. (1969) have shown that in rats and pigs reductions in the concentration of the total serum protein and albumin are closely related to primary protein malnutrition but not to undernutrition. In group 3 the reindeer have suffered both from protein malnutrition and from undernutrition. Hence the body-weight of these reindeer was also low compared with that of the animals in groups $I$ and 2.

The increase in the serum urea concentration in group 3, although there was a decrease in the total serum protein concentration, is not in agreement with the finding 
that the serum urea concentration reflects to a certain extent the protein content of the food (Preston, Schnakenberg \& Pfander, 1965; Maloiy, Kay, Goodall \& Topps, 1970). It has been reported also that blood urea recycling occurs in ruminants (SchmidtNielsen, Schmidt-Nielsen, Houpt \& Jarnum, 1957; Houpt, 1959; Packett \& Groves, 1965). Klein \& Schönheyder (1970) suggested that the reindeer also seems to be able to compensate for low nitrogen levels in forage by recycling $\mathrm{N}$ through the saliva. Hyppölä, Kiiskinen \& Hannila (1973) have assumed that in reindeer this recycling of urea must be especially important because of the very low protein content of the food in winter. The high value for serum urea in group 3 under extremely poor nutritional conditions may be connected with lowered microbial activity in the rumen. This assumption is in agreement with the higher serum urea concentration in those reindeer which had the lowest serum protein concentrations. In this group (group 3) severe mineral nutrient deficiencies have also been found (Hyvärinen \& Helle, 1973), which in connexion with general undernutrition might have been one important reason for the catastrophe in Enontekiö during the spring of 1973. Bones of dead animals were very thin and, apparently as a result of severe undernutrition, all fat in the medullas of the long bones had been consumed. It seems, however, that the reindeer cannot use their muscles as energy reservoirs because the activity of creatine phosphokinase $(\mathrm{CPK})$ in the serum of the reindeer of group 3 was not higher than that in groups I and 2 (Hyvärinen \& Helle, 1973) and clearly lower than that of group 4A and $5 \mathrm{~A}$ (Hyvärinen \& Helle, unpublished results). $\mathrm{CPK}$ in the serum is derived from the muscles. Luick et al. (1973) found that the glucose entry rate and plasma glucose concentration was greatly reduced when food was scarce. We measured blood glucose levels in the reindeer groups studied. There were no significant differences between the groups $\mathrm{I}-3(\mathrm{mean} \pm \mathrm{SE}(\mathrm{mmol} / \mathrm{l}$ whole blood): $3.62,0.12 ; 3.82,0.24 ; 3.70,0.24$ respectively) (Hyvärinen \& Helle, 1973). We suppose, therefore, that the importance of glucogenic amino acids as a source of glucose is not significant. During summer (groups $4 \mathrm{~A}$ and $\mathrm{B}$ ) and autumn (groups $5 \mathrm{~A}$ and $\mathrm{B}$ ), however, we found higher glucose levels than during winter (group $4 \mathrm{~A}, 4.68 \pm 0.24 \mathrm{mmol} / 1$ whole blood and group $5 \mathrm{~A}$, $4.53 \pm 0.24 \mathrm{mmol} / 1$ whole blood, Hyvärinen \& Helle, unpublished results), but we assume that these high values are for the most part caused by the stronger handling stress of these groups as compared to the winter groups (I-3).

Undernutrition in late winter is known to be serious for reproduction in caribou and reindeer (Pruitt, 1961; McEwan \& Whitehead, 1972). This was clearly also the situation in Enontekiö, for hardly any reindeer calves were to be found in the area that summer.

It is therefore necessary to organize an effective supplementary feeding system for reindeer during severe winters to avoid such catastrophes. This is now one of the most pressing problems for reindeer husbandry in Finland.

We are very grateful to the Academia Scientarum Fennica and to The Foundation for Research into Natural Resources in Finland for financial support. Thanks are extended to LuK Mauri Nieminen, Mrs Riitta Harjula and to members of the Reindeer Herding Association of Ala-Kitka for their valuable help. 


\section{REFERENCES}

Afanas'ev, V. P. (1963). Trudy mosk. vet. Akad. 47, 329 .

Annino, J. S. (1 964). Clinical Chemistry. London: J. \& A. Churchill Ltd.

Cameron, R. D. \& Luick, J. R. (1972). Can. Y. Zool. 50, 107.

Grimble, R. F., Sawyer, M. B. \& Whitehead, R. G. (I969). Br. F. Nutr. 23, 879.

Houpt, T. R. (1959). Am. F. Physiol. I97, I I 5.

Hyppölä, K., Kiiskinen, T. \& Hannila, P. (x973). Poromies 40, Part 2, 35.

Hyvärinen, H. \& Helle, T. (1973). Poromies 40, Part 4, 8.

Hyvärinen, H. \& Helle, T. (1974). Poromies 41, Part I, 8.

Isotalo, A. (1971). Lapin tutkimusseuran vuosikirja p. 28. Rovaniemi: Lapin tutkimusseura.

Kelsall, J. P. (1968). The Caribou. Ottawa: Queen's Printer.

Klein, D. R. (1968). F. Wildl. Mgmt 32, 350.

Klein, D. R. \& Schönheyder, F. (1970). Can. F. Zool. 48, 1437

Luick, J. R., Person, S. J., Cameron, R. D. \& White, R. G. (1973). Br. F. Nutr. 29, 245.

McEwan, E. H. (1968a). Can. F. Zool. 46, 1023.

McEwan, E. H. (1968b). Can. F. Zool. 46, ro3 I.

McEwan, E. H. \& Whitehead, P. E. (1970). Can. F. Zool. 48, 905.

McEwan, E. H. \& Whitehead, P. E. (I972). Can. F. Zool. 50, 43.

Maloiy, G. M. O., Kay, R. N. B., Goodall, E. D. \& Topps, J. H. (1 970). Br. f. Nutr. $24,843$.

Millipore Corp. (I 68). Phoro Slide Electrophoresis System. Bedford, Mass.: Millipore Corp.

Packett, L. V. \& Groves, T. D. D. (1965). F. Anim. Sci. 24, 341.

Pleuger (1969). Instructions for Use: Analytical Acrylophor. Wijnegem: Pleuger Sa.

Preston, R. L., Schnakenberg, D. D. \& Pfander, W. H. (1965). F. Nutr. 86, 28 r.

Pruitt, W. O. Jr (196r). F. Mammal. 42, $55^{\circ}$.

Schlieper, C. (1965). Praktikum der Zoophysiologie. Stuttgart: Gustav Fisher Verlag.

Schmidt-Nielsen, B., Schmidt-Nielsen, K., Houpt, T. R. \& Jarnum, S. S. (1957). Am. F. Physiol. 288,477 .

Steen, E. (1968). Symp. zool. Soc. Lond. 21, I17.

Sulkava, S. \& Helle, T. (1972). ist. int. Reindeer-Caribou Symp., University of Alaska, August 1972.

Varo, M. (1973). Poromies 40, Part I, 18.

Westerling, B. (1969). Poromies 36, Part $1,10$.

Westerling, B. (1973). Poromies 40, Part 3, 27.

Yousef, M. K., Cameron, R. D. \& Luick, J. R. (I97I). Comp. Biochem. Physiol. 40 A, 495. 